\title{
Jellyfishing in Europe: Current Status, Knowledge Gaps, and Future Directions towards a Sustainable Practice
}

\author{
Dori Edelist $^{1,2, *} \mathbb{C}$, Dror L. Angel ${ }^{1}\left(\mathbb{D}\right.$, João Canning-Clode ${ }^{3,4}\left(\mathbb{C}\right.$, Sonia K. M. Gueroun ${ }^{3,5} \oplus$, Nicole Aberle ${ }^{6} \oplus$, \\ Jamileh Javidpour ${ }^{7}$ and Carlos Andrade ${ }^{5,8}$ (D)
}

1 Recanati Institute for Maritime Studies and Department of Maritime Civilizations, Charney School of Marine Sciences, University of Haifa, Haifa 31905, Israel; dangel@univ.haifa.ac.il

2 Israel Society of Ecology and Environmental Sciences. Jaffa 6775323, Israel

3 MARE-Marine and Environmental Sciences Centre, Agência Regional para o Desenvolvimento da Investigação Tecnologia e Inovação (ARDITI), 9020-105 Madeira, Portugal; jcanning-clode@mare-centre.pt (J.C.-C.); sgueroun@mare-centre.pt (S.K.M.G.)

4 Smithsonian Environmental Research Center, Edgewater, MD 21037, USA

5 Maricultura Centre of Calheta, 9370-133 Madeira, Portugal; carlos.a.andrade@madeira.gov.pt

6 Department of Biology, Trondhjem Biological Station, Norwegian University of Science and Technology (NTNU), N-7491 Trondheim, Norway; nicole.aberle-malzahn@ntnu.no

7 Department of Biology, University of Southern Denmark, 5230 Odense M, Denmark; jamileh@biology.sdu.dk

8 Interdisciplinary Centre of Marine and Environmental Research (CIIMAR/CIMAR), University of Porto, 4099-002 Porto, Portugal

* Correspondence: blackreefs@gmail.com; Tel.: +972-525-445-049

Citation: Edelist, D.; Angel, D.L.; Canning-Clode, J.; Gueroun, S.K.M.; Aberle, N.; Javidpour, J.; Andrade, C. Jellyfishing in Europe: Current Status, Knowledge Gaps, and Future Directions towards a Sustainable Practice. Sustainability 2021, 13, 12445. https://doi.org/10.3390/su132212445

Academic Editor: Mario D’Amico

Received: 12 October 2021

Accepted: 9 November 2021

Published: 11 November 2021

Publisher's Note: MDPI stays neutral with regard to jurisdictional claims in published maps and institutional affiliations.

Copyright: (C) 2021 by the authors Licensee MDPI, Basel, Switzerland. This article is an open access article distributed under the terms and conditions of the Creative Commons Attribution (CC BY) license (https:/ / creativecommons.org/licenses/by/ $4.0 /)$.
Abstract: Jellyfish are often described as a nuisance species, but as our understanding shifts to more ecosystem-based conceptions, they are also recognized as both important components of marine ecosystems and a resource for humans. Here, we describe global jellyfish fisheries and review production, fishing methods, and applications based on the existing literature. We then focus on future development of a European jellyfish fishery based on current and recent EU research initiatives. Jellyfish have been a staple food in East Asia for eons and now show a potential for non-food applications as well. The main fishing methods are mostly traditional, with set-nets, driftnets, hand-nets, and scoop-nets utilizing small crafts or beach-seines. All require a lot of manual labor, thus providing vital, albeit seasonal, occupation to weaker populations. Larger commercial vessels such as purse seines and trawlers are newly introduced métiers which may enable a larger catch per unit effort and total catch, but pose questions of selectivity, bycatch, vessel stability, and transshipment. Social concerns arising from the seasonality of jellyfish fisheries must be met in SE Asia, Latin America, and in any location where new fisheries are established. In the EU, we recognize at least 15 species showing potential for commercial harvesting, but as of 2021, a commercial fishery has yet to be developed; as in finfish fisheries, we advise caution and recognition of the role of jellyfish in marine ecosystems in doing so. Sustainable harvesting techniques and practices must be developed and implemented for a viable practice to emerge, and social and ecological needs must also be incorporated into the management plan. Once established, the catch, effort, and stock status must be monitored, regulated, and properly reported to $\mathrm{FAO}$ by countries seeking a viable jellyfish fishery. In the near future, novel applications for jellyfish will offer added value and new markets for this traditional resource.

Keywords: jellyfish; fisheries; jellyfishing; European Union; blue growth

\section{Introduction}

Jellyfish and particularly scyphomedusae have widely been regarded more as a nuisance than a beneficial resource [1], but they are newly recognized as contributing to many ecosystem services [2]. Jellyfish outbreaks can have serious and deleterious impacts on humans and socio-economic activities, including stinging of bathers, economic losses 
for tourism, clogging of cooling water intakes of ships and coastal power and desalination plants, damages to fisheries and aquaculture [1,3], and references therein [4,5].

On the other hand, jellyfish are a natural ecosystem component providing various services, such as sequestering carbon, offering habitats for juvenile fish [6], contributing to medical advances [7,8], cancer therapy [9], and even enhancing biodiversity [4]. Some researchers (e.g., [2]) have suggested that jellyfish blooms may be portrayed in a positive light as they may contribute to all four categories of ecosystem services (regulating, supporting, provisioning, and cultural services).

The global demand for jellyfish biomass is on the rise [10]. Humans have fished and used jellyfish for millennia, especially in China, where they are a staple food [11]. China continues to be the main producer and consumer of jellyfish, although Japan and Korea are emerging as large markets [12]. Other countries emerging as significant producers include Thailand, India, Vietnam, Indonesia, and Mexico [10]. Recent advances have been achieved in assessing the value of jellyfish in traditional industries and in finding novel uses for jellyfish products [13-15], (www.gojelly.eu) (access on 25 August 2021), including as (1) marine natural products for biomarkers and biomedical applications [16], (2) agricultural fertilizer [15,17,18], (3) farmed fish and animal feed [9,19], (4) a collagen source [20-22], (5) microplastic filters in wastewater treatment plants [23], and (6) novel human food products $[8,14,24,25]$, along with (7) the exploration of jellyfish palatability in western markets [14]. This is expected to lead to new markets for jellyfish as a raw material and thus to large-scale jellyfish fisheries or even aquaculture and jellyfish cultivation. However, there is an urgent need to implement state-of-the-art fishing techniques and management tools to enable a sustainable jellyfish fishery in Europe.

To date, large numbers of jellyfish are harvested as bycatch and are typically discarded [10]. Several nations outside China, especially in Southeast Asia and Central America, have started jellyfishing to meet the demand for jellyfish as a human food source. While jellyfish blooms have been considered a consequence of overfishing and "fishing down marine food webs" [26], edible jellyfish appear to have declined in Chinese coastal waters due to their own overexploitation [13]. To prevent this, there is a need to make jellyfish harvest sustainable, both ecologically and socio-economically [11,27-29]. While commercial jellyfish fishing may reduce the number of adult jellyfish, it will not stop jellyfish blooms [27]. Bycatch, effort regulation, and habitat integrity need to be effectively managed for a viable practice to grow. A selective fishery for commercial species is not expected to remove other nuisance jellyfish that might bloom after removal of the target species. Even when a sustainable jellyfish fishery is implemented, conservation challenges may arise if market-driven restocking of jellyfish populations takes place, as it is currently the case in China, where the most valuable edible species, Rhopilema esculentum, is restocked in the Yellow Sea [30].

While significant efforts were made to evaluate jellyfish fisheries worldwide, key data regarding product diversification, species and market characterization, palatability, stock assessment capabilities, industrial fishing methods, and seasonal, socio-economic, and operative structures are missing with respect to European jellyfish fisheries. This study aims to review the existing literature on jellyfish fisheries, to update some production figures, and to outline novel products, potential markets, and fishing methods. Further, potential commercial jellyfish species in European seas are collated, and needs and knowledge gaps are identified to allow for sustainable and efficient jellyfish harvesting, emphasizing the European seas.

\section{Methods}

A comprehensive literature search was conducted of scientific papers, books, book chapters, theses, and reports published between 1980 and 2021 and recorded in Google Scholar using the keywords "Jellyfish Fishery" or "Jellyfish Fisheries" or "Jellyfish Fishing" or "Jellyfish Catch". Patents, as well as citations of other works already included, were excluded from the search results and the publications were screened for relevance, to 
include only original sources. The remaining publications were surveyed for information on jellyfish catches (species and biomass), fishing techniques, and processing methods. These were supplemented by publications cited by Brotz [10] that did not appear in the initial Google Scholar search. Target jellyfish species, biomass, and fishing methods were extracted from the publications and supplemented by data from recent jellyfish harvesting activities. Due to the sparsity of available literature in English, data was complemented with observations made during a 2018 visit to Shandong fisheries in China. Additional aspects seen as vital for sustainability of the practice were also reviewed in order to facilitate the planning of a future sustainable jellyfish fishery in the EU. Catch data were downloaded from the FAO repository of global capture production of the fishery statistical collections-http:/ /www.fao.org/fishery/statistics/global-capture-production/ en (accessed on 17 August 2021).

\section{Results and Conclusions}

\subsection{Literature Survey}

A total of 648 publications referring to jellyfish fisheries were found in the search. Subsequently, 89 relevant publications were validated as contributing to jellyfish fisheries, their management, fishing methods, landings, markets, and products between 1980 and 2021. The number of relevant publications increased with time, particularly indicating our increasing knowledge in the 21st century (Figure 1). Most of the earlier publications were from Japan or North America, but since the turn of the century, important contributions have also been added from Europe, Australia, South America, and China.

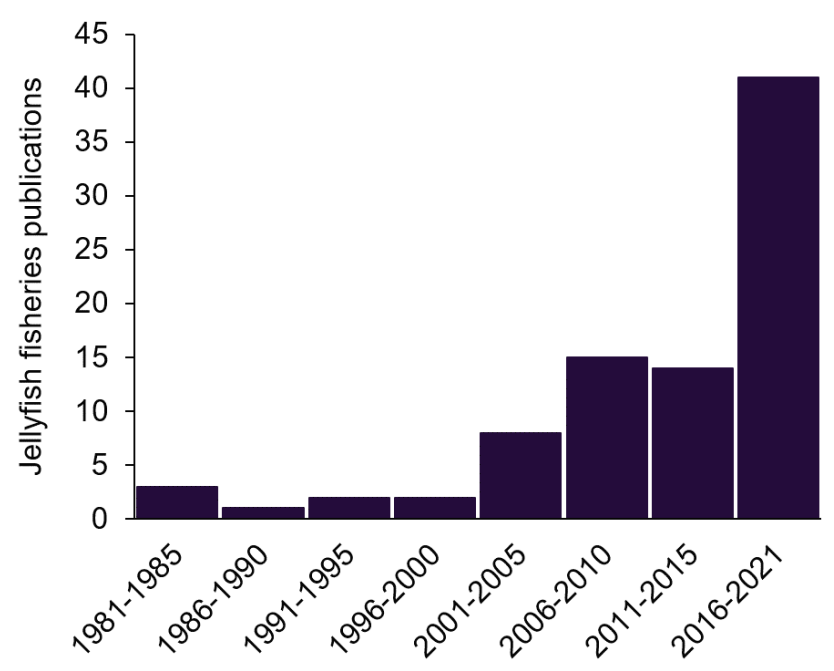

Figure 1. The number of jellyfish fisheries publications found in a Google Scholar search, after screening for relevance.

Important and often cited contributions were made at the turn of the century $[11,13]$. By far the most extensive efforts to date were carried out in a series of reviews by Brotz et al. $[10,31,32]$. These comprise the main body of knowledge. Recent publications from SE Asia, e.g., [9,30,33,34] and America [35-37] update and complement them. Several international initiatives were covered in Brotz [10] and Brotz and Pauly [31], but EU efforts emerge from this survey as almost nonexistent (Figure 2), which provides us with a rare opportunity to lay the foundations for a sustainable practice before the establishment of a commercial fishery. 


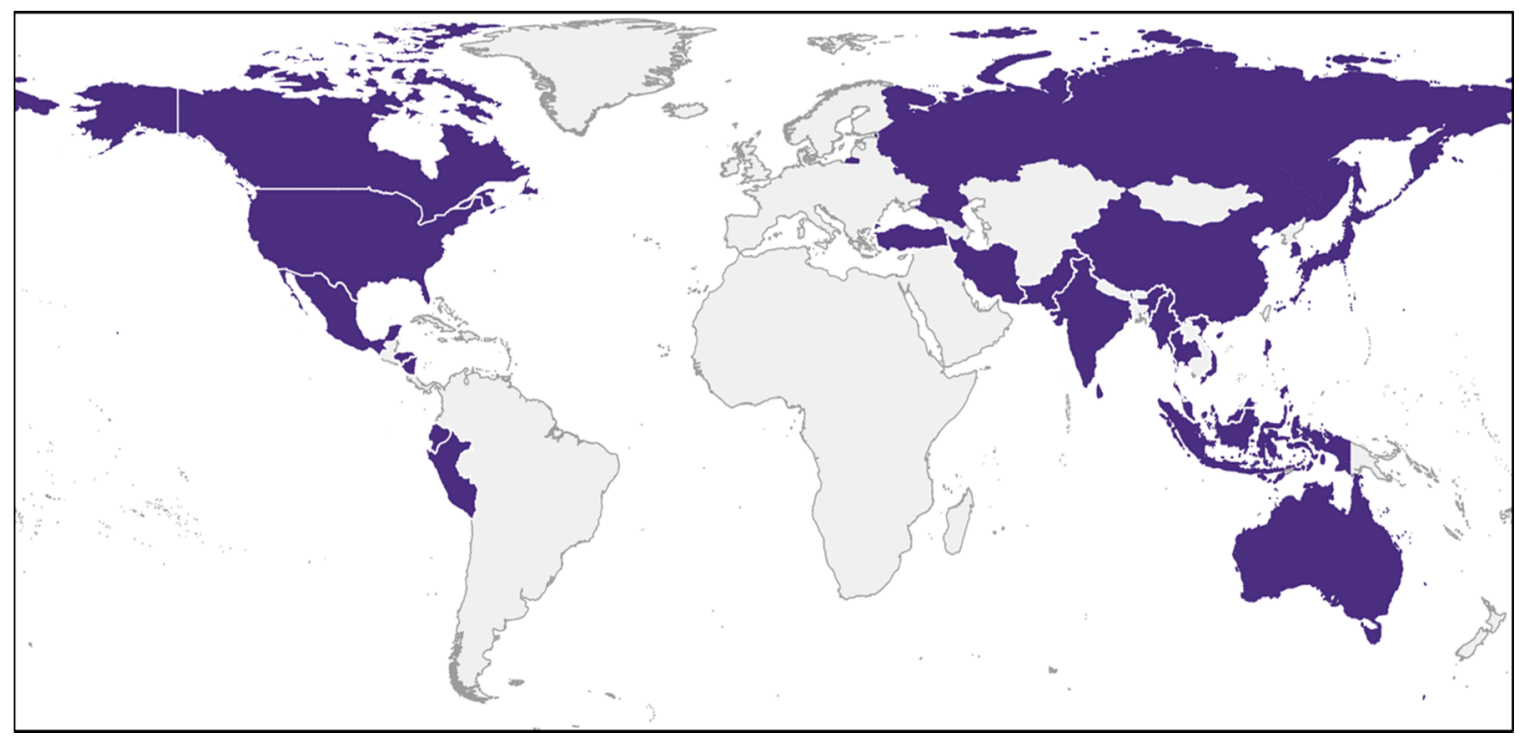

Figure 2. Countries with past and/or present records of jellyfish fisheries (Sources: Brotz and Pauly [31], present study).

Other recent publications add to our knowledge on potential and existing fisheries: in Asia, China is still the world leader in production, consumption, and even aquaculture of jellyfish, and Dong et al. [30] have recently advanced stock enhancement and assessments for R. esculentum in Liaodong Bay (China), which forms the base for their fishery [38]. Hatcheries produce large numbers of juvenile jellyfish that are supplied to farmers to grow in tanks and ponds to eventually release medusae into the ocean for restocking purposes [30]. The jellyfish fishing season is very short (days to weeks). Fishing grounds and fishing methods are well defined and monitored, and life history, habitat, and natural dispersal of the species are known [30]. The Liaodong fishery thus provides an extreme example of a human-dominated and human-controlled process. This should be complemented by information on the impacts of jellyfish fishery on the ecosystem and other services it renders in order to ensure sustainable management from a wider perspective [4]. In India, jellyfishing started in 1980, mainly of Crambionella annandalei, but, similar to the R. esculentum fishery in Japan, it was not reported to FAO (Figure 3). Behera et al. [39] elaborate on the scale and practice of Indian jellyfish harvesting and Baliarsingh et al. [40] discuss the distribution and monitoring of jellyfish in India. Up to 33,000 tons per annum of C. annandalei are reported as landed by gillnets in Andhra Pradesh alone, out of $\sim 100,000$ tons for the entire country [39]. This seasonal monospecific fishery employs 60-70 small vessels with 6-7 persons on each boat, deploying nets at 10-40 m depth. Other Indian jellyfish fisheries were previously described from Tamil Nadu, Odisha, West Bengal, Karnataka, and Gujarat [8]. Nishikawa et al. [41] presented an update on fisheries in Thailand, and in Pakistan two species of scyphozoans, Catostylus perezi and Rhopilema hispidum, are commercially exploited [33] alongside a candidate species, Crambionella orsini [42]. In America, Lopez-Martinez [43] described the growth of Stomolophus meleagris in the Gulf of California, facilitating stock assessment and estimates on harvest frequency, which are a prerequisite to establish a sustainable fishery. Fahrenbruch [28] and Cruz-Colín et al. [29] provided information on Latin American jellyfish fisheries, focusing on Nicaragua and Mexico, respectively, and discussed the magnitude and practices in light of economic and often neglected social aspects of jellyfish fisheries. Bazi et al. [36] provided updates on Brazilian jellyfish fisheries. The species Rhacostoma atlanticum, Chiropsalmus quadrumanus, and Lychnorhiza lucerna are common as bycatch in finfisheries in Brazil and were recently considered as potential species for human consumption after protocols for processing were developed and jellyfish distribution and abundances were modeled [36]. In Australia, Rault and Gaston [44] estimated jellyfish stocks for Catostylus mosaicus using drones, highlighting the need for a rapid, accurate stock assessment, considering the boom- 
and-bust nature of jellyfish blooms. In Africa, Adongo [45] described jellyfish belonging to four families (Catostylidae, Chirodropidae, Rhizostomatidae, and Pelagiidae), bycaught in artisanal net fisheries landings in Ghana as a potential resource. In Europe, Cruz [46] described the nonindigenous Blackfordia virginica as a potential food source in Portugal and Rodriguez et al. [37] added Cyanea capillata, Cyanea lamarckii, and Rhizostoma luteum to the list of species for a potential fishery. Risk-based approaches to the health and safety of jellyfish (e.g., Catostylus tagi, Aurelia coerulea, Cotylorhiza tuberculata, Rhizostoma pulmo) consumption were developed and reviewed by several groups [24,47-51], and palatability and potential western markets for jellyfish were tested [14].

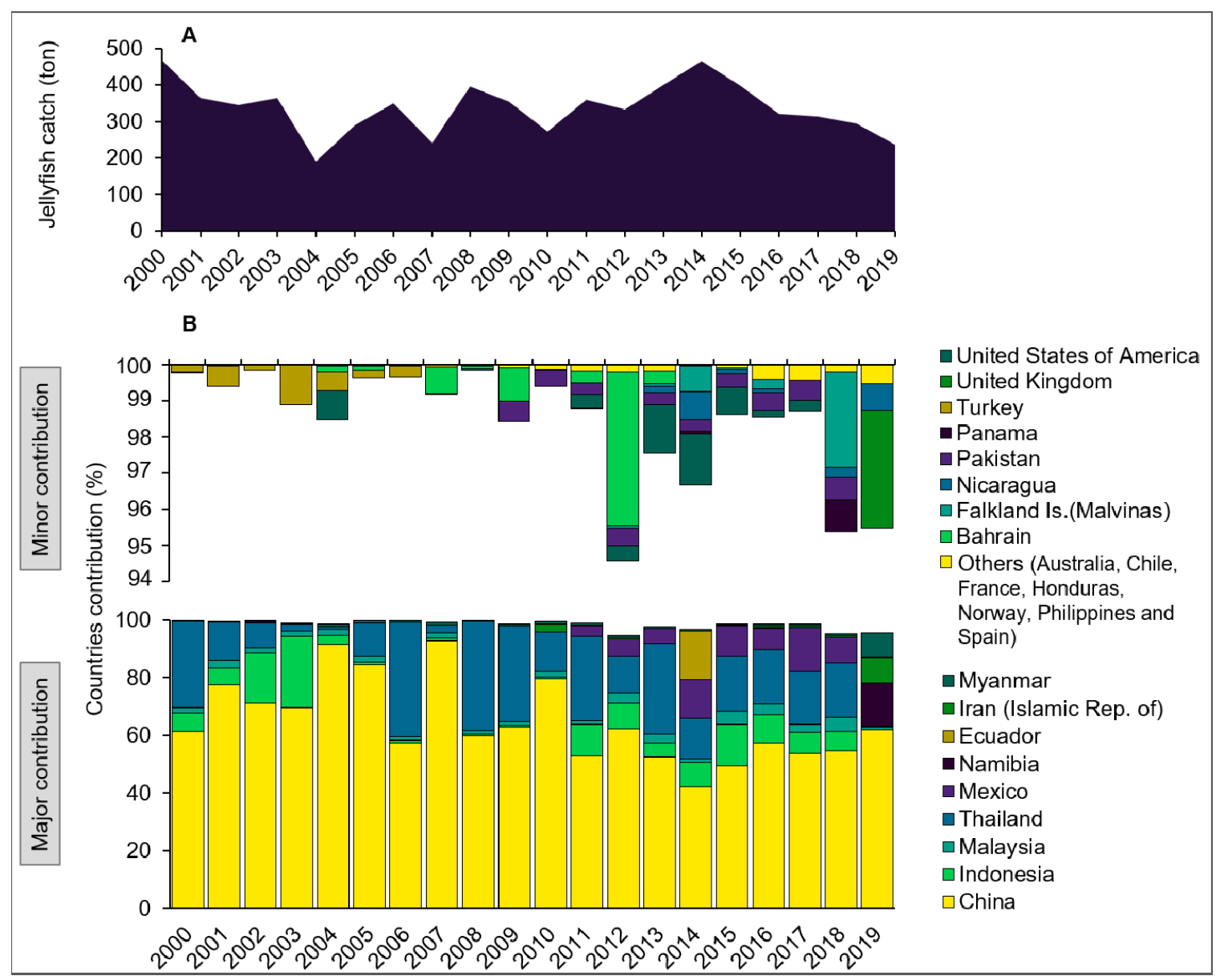

Figure 3. Global annual jellyfish catches from 2000 to 2019 in thousands of tons (A) and catch proportion by country (B) as reported to FAO. Note that catches from India (mainly Crambionella spp.), Japan (R. esculentum), Vietnam, and from several other countries are not included as they are reported to FAO under "miscellaneous invertebrates". Source: FAO (2021).

The increase in published papers on jellyfish fisheries (Figure 1) mirrors an increase in publications dealing with damages caused by jellyfish [5]. It stands to reason that calls for reduction of jellyfish populations by fishing them will keep increasing [52] alongside pleas for cautious, responsible fisheries [27].

\subsection{Jellyfish Harvest}

While claims of a human driven global increase in jellyfish populations may have been exaggerated or even erroneous [53], jellyfish blooms are expected to persist locally and temporally [54]. The average annual catch of jellyfish in SE Asia was estimated at 169,000 tons (wet weight) between 1988 and 1999 and the global catch at approximately 321,000 tons [11]. This catch has since almost tripled, reaching 900,000 tons in 2016, harvested by 19 countries, predominately in SE Asia [31]. More than half of the catch is 
consumed in China, by far the largest producer and importer of jellyfish. Thailand, India, Vietnam, Indonesia, and Latin America are emerging producers, while Japan and Korea are emerging markets. In 2020, despite a surge of novel applications, almost all landed jellyfish biomass was still used as food for humans in SE Asia. While this is not reflected in the official data reported by FAO (Figure 3), these higher figures likely represent more accurate estimates of the actual catch, considering common underreporting and conversion of the reported catch to wet weight [26,31]. For example, the typical dry weight of $R$. esculentum is a mere $15 \%$ of its wet weight [31].

Brotz [10] reported catches that are about double those reported in Figure 3 and are much closer to actual production, as they include conversion to wet weight. The large differences in reported data are considered to be mainly a result of Chinese underreporting to FAO [31], the absence of India, Japan, Korea, and Vietnam (Figure 3), and a lack of detailed information on whether fresh, dried, or semi-dried jellyfish biomass was reported. This highlights the need for standardized reporting protocols, as the processed dried product typically represents a mere $8-15 \%$ of the wet weight [10]. Some of the declines in global production may be explained by the volatile nature of some newly established fisheries in the early years, such as in Thailand after the turn of the century, or in Ecuador and Mexico in recent years where a steady practice has yet to be established [28].

The high interannual and seasonal variability in landed biomass (mainly in Thailand and Latin America) and the decline in landings since 2015 (Figure 3) reflect the instability of jellyfish populations and jellyfishing operations. A sustainable management of jellyfish resources thus requires adaptive regulations and modular infrastructure that allow for rapid deployment, stowing, and re-use of gear for a seasonal fishery to develop alongside a fair and long-term employment program for fishers and other workers once the fishery closes for the season. Such an adaptive management process should rely on ecosystem models and jellyfish stock assessments [31] that determine maximum sustainable yields (MSY), quota allocations, appropriate fishing techniques, bycatch regulations, and fishery opening-closure procedures. In addition, a profound knowledge on the ecological roles of target jellyfish species in marine food webs needs to be obtained and implemented into management strategies [55]. Unfortunately, the present review finds that almost all jellyfish fisheries are managed to increase short-term profits rather than plan for more sustainable long-term goals.

\subsection{Edible Jellyfish Species}

There are about 400 species of Scyphomedusae, and among these about 92 species of rhizostomes [56], which are considered the top choice for human consumption [11]. To date, about 40 species of jellyfish are commercially fished for food purposes. Despite this, jellyfish did not appear on the public statistics of FAO until very recently and were either missing entirely or listed under "other marine invertebrates" [31]. In 2020, jellyfish were finally featured as a separate group in FAO official reports. However, they are only divided into two major taxa (Rhopilema spp. and Stomolophus melegaris) representing catches from Asia and America, respectively, as well as minor mentions of Chrysaora plocamia from Chile and Catostylus spp. from Pakistan [31]. At the turn of the century, at least 11 species in five families were recognized as being commercially harvested in Southeast Asia [11], setting the stage for a later expansion of jellyfishing to new ecoregions and species in the 21st century. Brotz [10] listed 39 jellyfish taxa which have been commercially utilized for food purposes. The present review adds several species that show potential for a commercial jellyfish fishery, although they are not yet consumed by humans on a large scale, namely, Rhacostoma atlanticum, Chiropsalmus quadrumanus in Brazil [36], Cyanea capillata, Cyanea lamarckii and Rhizostoma luteum in the eastern Atlantic [37], and Aurelia coerulea, Mnemiopsis leidyi, and Chrysaora hysoscella in European Seas (present review). Most commercially exploited species belong to the order Rhizostomeae, characterized by large and rigid bells, which are more amenable to processing [57]. The main two species currently harvested are Rhopilema esculentum and Nemopilema nomurai. While R. esculentum is the most sought-after target 
species and is also artificially enhanced in restocking operations in China [30], N. nomurai is also widely exploited in East Asia, probably in much larger quantities than those appearing in FAO data [10]. Within-species variations in morphological features, size, and coloration often render jellyfish taxonomy and species identification challenging without genetic studies. It is thus probable that several different species are currently identified under a single species, e.g., [58,59].

\subsection{Non-Human-Food Uses for Jellyfish Biomass}

Today, main non-food uses of jellyfish include (1) pharmaceutical applications, e.g., purified collagen [60], anticoagulants, mucins, antimicrobiotics, and antihypertensive peptides [10] and therein, as well as bioactive compounds [8] and antioxidant peptides [22]; (2) cosmetics based on moisturizing [61], anti-aging, and UV protection properties of jellyfish extracts $[20,62,63]$; (3) agriculture as organic fertilizers and pesticides $[17,64,65]$ and seed germination agents for sand dune restoration [15]; (4) animal and aquaculture feeds [10] and therein $[66,67]$; (5) biotech, with Nobel Prize-winning green fluorescent protein (GFP) hailed as "one of the most useful tools in modern medicine" [7]; and (6) decontamination development using coagulative properties of jellyfish mucus for capturing nano- and microparticles $[23,68,69]$.

\subsection{Jellyfishing Methods}

A variety of vessels and gear are used for jellyfishing. Bottom trawlers are used in places like the Georgia cannonball jellyfish fishery in the US [35] and China [10]. However, most fishing is still performed from artisanal vessels using dip-nets [10]. Suction fishing and process automation may help boost the efficiency of harvesting jellyfish, as demonstrated by Chi [70], but are still under development. Omori and Nakano [11] described jellyfish as being caught by set-nets, drift-nets, hand-nets (Figure 4), scoop-nets, beach-seines, and hooks.

Further, weirs, purse seines and trawlers, and gear combinations may be used, such as in Japan and Malaysia where jellyfish are typically concentrated using set-nets and then collected using dip-nets (Figure 4) [10]. A combination of methods is also popular among the fishermen in small communities north of Qingdao, China (J. Javidpour and C. Andrade, personal communication). They use gill nets placed for about a week along the coast perpendicular to the main current. These nets have typical mesh sizes of $\sim 10 \mathrm{~cm}$ and are about $30 \mathrm{~m}$ long and $20 \mathrm{~m}$ deep. Anchors secure nets at both ends, with two accessory anchors in between, and floats are used on the surface. Fishermen visit the site daily and harvest jellyfish of variable sizes (mostly above $2 \mathrm{~kg}$ ) with a dip net. The average yield per trip is about $50 \mathrm{~kg}$ (J. Javipour and C. Andrade, personal communication). Operations using suction to extract jellyfish from the water into ship hulls were attempted recently in China [70] and Mexico (D. Edelist, personal communications), but such endeavors are still mostly in the experimental phases [70]. As both food and non-food use emerge and proliferate $[2,11,15,60]$, problems such as "scarring" of jellyfish bells by trawl or other nets cutting into the flesh may be overcome by using thicker netting material, or by division of the catch into edible and non-edible phases.

Jellyfishing tows often do not exceed five minutes when fishing in dense blooms [11]; and when trawling for jellyfish in Georgia (US), vessels are allowed to drag nets for a maximum of $30 \mathrm{~min}$ to reduce marine mammal and sea turtle bycatch and mortality [35]. Within 3 NM from shore, trawlers are required to use turtle excluder devices (TEDs) in order to reduce unwanted bycatch; however, some jellyfishers operate in federal waters, where these state laws do not apply [32]. 


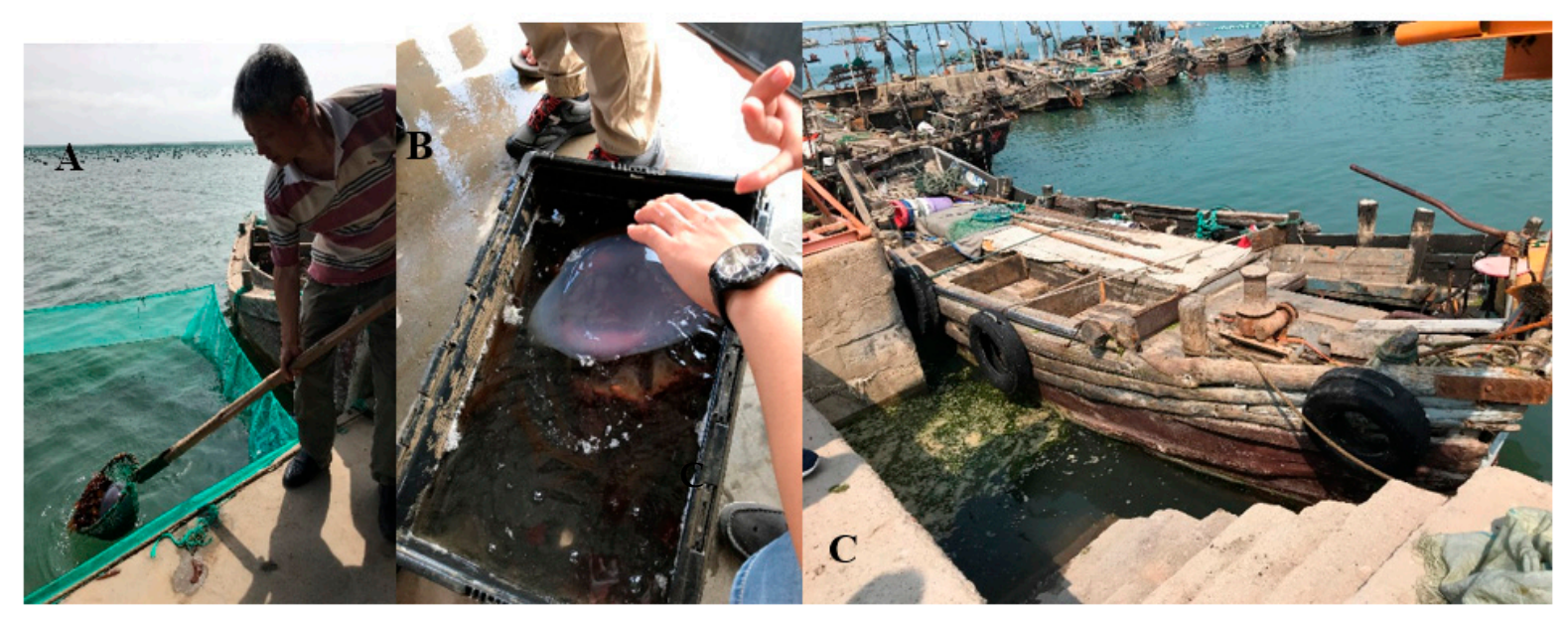

Figure 4. A fisherman collects a jellyfish at sea using a small hand net, after jellyfish concentration in a surface net structure (A). Animals are directly transferred to plastic boxes or buckets and often kept individually (B). Many artisanal fishers use traditional and rather primitive boats (C) for the capture of jellyfish. Source: J. Javidpour.

In addition to traditional methods (i.e., fishing), there may be other means to collect jellyfish that have not been exploited yet. To date, there is no known utilization of jellyfish (for food) that are captured on screens and intake filters at coastal power utilities or desalination plants despite the massive amounts that accumulate in these facilities. Development of non-food uses would allow for the use of jellyfish of less complete form and shape, facilitating such innovative solutions, or even the collection of stranded specimens from the shore.

Jellyfishing is mainly a nearshore activity using small $(5-10 \mathrm{~m})$ boats powered by outboard engines [10]. Fishers in northern Qingdao make a 20-30 nautical mile trip in 8-10 $\mathrm{m}$ long, $20 \mathrm{HP}$ boats to set their nets (J. Javipour and C. Andrade, personal communication; Figure 4, right). Conversely, in the Gulf of Bohai, the Chinese jellyfish fleet includes 200 government-issued $17 \mathrm{~m}$ long wooden boats with diesel engines fishing with trawls and set nets [71]. Jellyfish are visually located in surface waters and most often collected using dip-nets or scoop-nets. Dip-nets are considered highly selective fishing gear, with little bycatch, while set nets, purse seining, and particularly trawling might entail larger amounts of bycatch [11]. Moreover, the quality of the catch by a dip-net is considered higher than that of set nets or trawls as jellyfish are less stressed and scarred when fished by hand (Figure 5).

As many fish and invertebrate species associate with jellyfish in different life stages, bycatch also needs to be accounted for in industrial fisheries. Larger mesh sizes may reduce bycatch of smaller individuals, including smaller medusae. Several countries (e.g., Australia, USA, Mexico) have implemented minimum jellyfish size limits (MSLs). In Australia, fishers targeting jellyfish are required to use dip-nets to ensure high selectivity [10] and a minimum size limit of $23 \mathrm{~cm}$ (bell diameter) is designated for C. mosaicus, well above the size at which sexual maturity is attained-13-16 cm [10]. Nevertheless, the effectiveness of MSLs in jellyfish fisheries has not been evaluated scientifically [32]. Moreover, larger mesh sizes or thinner netting material might damage the bells of the bigger and more valuable medusae.

Jellyfishing may also require structural changes to vessels. Large jellyfish loads might interfere with vessel stability and increase the risk of capsize. The small crafts typically used in jellyfish fisheries normally catch $1-5$ tons of jellyfish [32] and their capacity is limited by safety and sea state issues. Placing baffles in the holds of vessels may reduce shifting of the catch in rough seas [10] and thus reduce the risk of capsize. Another severe (but rarely lethal) risk is stinging and irritation to the fishers [72]. Fishers typically handle the catch bare-handed, as gloves may be awkward, uncomfortably hot, or simply not 
available [32]. Development of a per species risk assessment and safe handling protocols is thus deemed necessary.

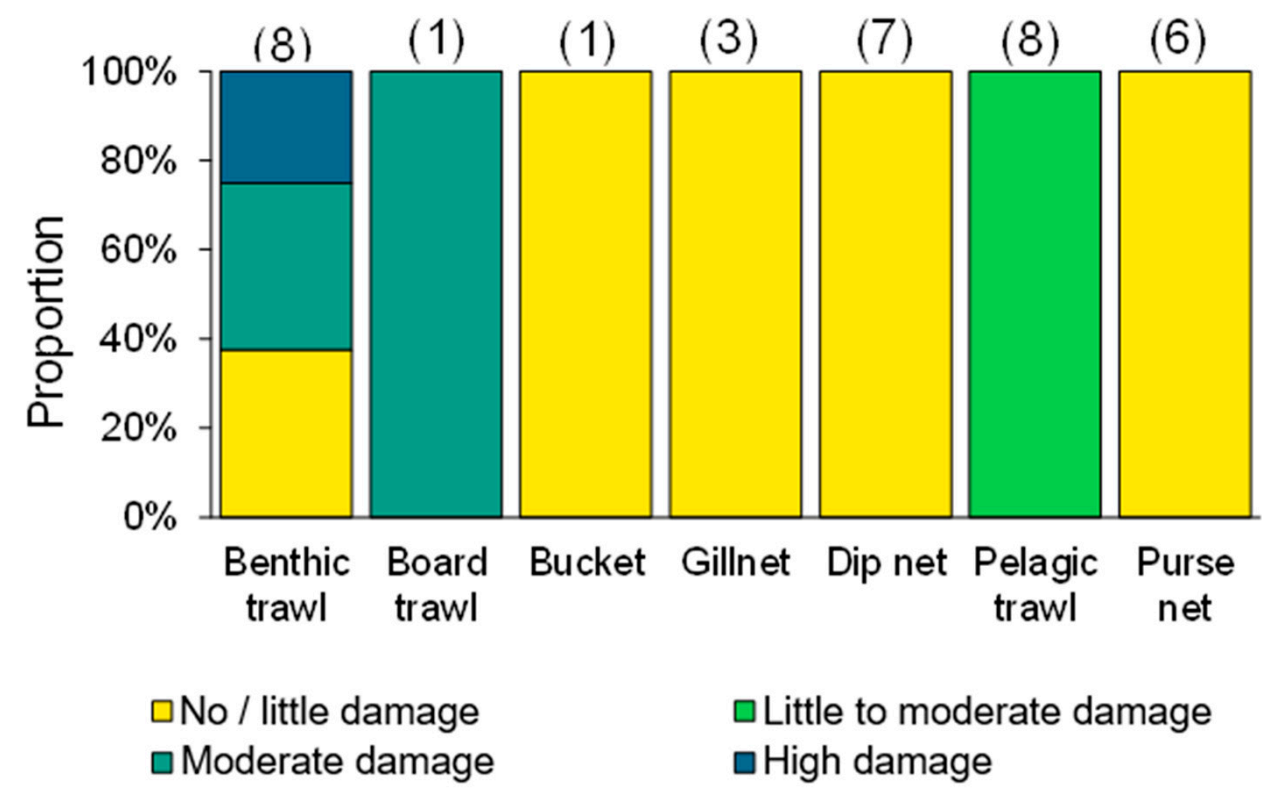

Figure 5. Damage assessment for jellyfish extracted in different fishing methods $(n=34$; figures above each bar represent the number of fishing operations). Source: GoJelly Project (www.gojelly.eu) (access on 25 August 2021).

JF fisheries are characterized by large inter-annual fluctuations and short fishing seasons, typically two to four months at most $[10,11]$. Jellyfish fishers in China and the Caribbean may travel along the coast, following the bloom in order to harvest its biomass [10,28]. Jellyfishing is usually a daytime operation; however, nocturnal jellyfishing may be beneficial during the summer season or in tropical areas, to prevent the catch from getting spoiled, as often jellyfish must be processed on land within hours of extraction and warmer temperatures might shorten this transition period considerably [32]. Another benefit of nocturnal jellyfishing is derived from the vertical diel migration of jellyfish, as they often ascend to the surface at night [13] (but see [39]).

\subsection{Jellyfish Fisheries in European Seas and Adjacent Waters}

In the European Seas, Turkey was the only country to run a fully commercial, largescale jellyfish fishery, between 1984 and 2006 (Figure 3) [73]. Catches of Aurelia spp. (for human and pet food), and Rhizostoma pulmo and Rhopilema nomadica (for human food) reached a maximum of $4000 \mathrm{t} \times \mathrm{y}^{-1}$, totaling 14,862 tons for the entire period. Most of this catch originated from the Black Sea (53\%) and the Marmara Sea $(31 \%)$, with a smaller amount from the Mediterranean (11\%) and the Aegean (4\%) Seas [10]. It is postulated that R. pulmo was a main target species in the Black Sea [74]. By 2008, this practice ceased, and Aurelia spp. was since mentioned only as a bycatch discarded species in the Black Sea [75]. Today, despite calls for reinstalling a Mediterranean jellyfish fishery [54], no commercial fishery is active.

In the only other semi-commercial scale fishery in Europe [60], the barrel jellyfish Rhizostoma octopus is commercially harvested from the Bay of Biscay and Wales (Atlantic), respectively, to produce medical-grade collagen. In 2015, a total of 4.3 tons (wet weight) of R. octopus was collected for this purpose [60].

Norway has considered harvesting the mesopelagic Periphylla periphylla [76]. Despite its large abundance in Norwegian fjords, a commercial fishery has still not been developed due to a lack of demand and market (R. Tiller, A. Hosia, R. Slizyte, personal communication). In Israel, $\sim 100 \mathrm{~kg}$ (wet weight) of $R$. nomadica was harvested in 2018 as a pilot for export 
to China. Both R. nomadica and R. pulmo were approved by Chinese practitioners as palatable; however, a lack of investment and interest from regulatory bodies currently delays the establishment of such a fishery (D. Edelist, personal communication). To assess the applicability of developing jellyfishing in European seas, the main relevant species are identified here with their distribution and references for the types of fisheries that may be developed for them (Table 1).

Table 1. Main jellyfish species in EU waters that show potential for a commercial fishery. $\left(^{*}\right)$ : Non-indigenous species.

\begin{tabular}{|c|c|c|c|}
\hline Species & $\begin{array}{l}\text { Distribution in European } \\
\text { Seas and Ecoregions } \\
\text { (Following Spalding } \\
\text { et al., 2007) }\end{array}$ & Explored Uses & $\begin{array}{c}\text { Reference for Potential } \\
\text { Fisheries Development in } \\
\text { European Seas }\end{array}$ \\
\hline Aurelia spp. & $\begin{array}{l}\text { Baltic Sea, North Sea, Celtic } \\
\text { Seas, Bay of Biscay and Iberia, } \\
\text { Mediterranean Sea, Black Sea, } \\
\text { Macaronesia: } 24-36,44\end{array}$ & $\begin{array}{l}\text { Food, animal feed, } \\
\text { pharmaceuticals, fertilizer, } \\
\text { bioactive molecules, } \\
\text { microplastic filter }\end{array}$ & $\begin{array}{l}{[10,24,31,58,77,78]} \\
\text { present study }\end{array}$ \\
\hline Catostylus tagi & $\begin{array}{c}\text { Bay of Biscay and Iberia } \\
\text { (Tagus estuary) } \\
\text { Macaronesia: } 27\end{array}$ & $\begin{array}{l}\text { Food, pharmaceuticals, } \\
\text { animal feed }\end{array}$ & {$[3,47,79,80]$, present study } \\
\hline Chrysaora hysoscella & $\begin{array}{c}\text { Baltic Sea, North Sea, Celtic } \\
\text { Seas, Bay of Biscay and Iberia, } \\
\text { Mediterranean Sea, } \\
\text { Macaronesia }\end{array}$ & Food, pharmaceuticals & {$[77,81-83]$} \\
\hline Cotylorhiza tuberculata & Mediterranean Sea: 24-36, 44 & $\begin{array}{l}\text { Food, pharmaceuticals, } \\
\text { animal feed }\end{array}$ & $\begin{array}{c}{[10,24,84]} \\
\text { present study }\end{array}$ \\
\hline Cyanea capillata & $\begin{array}{c}\text { Baltic Sea, North Sea, Celtic } \\
\text { Seas, Bay of Biscay, and Iberia: } \\
21-29\end{array}$ & Food, fertilizer & $\begin{array}{l}{[31,77]} \\
\text { present study }\end{array}$ \\
\hline Cyanea lamarckii & $\begin{array}{c}\text { Baltic Sea, North Sea, Celtic } \\
\text { Seas, Bay of Biscay, and Iberia: } \\
21-29\end{array}$ & Food, feed & $\begin{array}{l}{[31,77]} \\
\text { present study }\end{array}$ \\
\hline Mnemiopsis leidyi * & $\begin{array}{c}\text { Baltic Sea, North Sea, } \\
\text { Mediterranean Sea, Black Sea: } \\
24,25,31-36,44\end{array}$ & Microplastic filter & $\begin{array}{l}\text { [85-87], } \\
\text { present study }\end{array}$ \\
\hline Pelagia noctiluca & $\begin{array}{c}\text { Celtic Seas, Bay of Biscay and } \\
\text { Iberia, Mediterranean Sea, } \\
\text { Black Sea, Macaronesia: 21, } \\
\text { 25-36 }\end{array}$ & Food, bioactive molecules & $\begin{array}{l}{[31,88,89]} \\
\text { present study }\end{array}$ \\
\hline Periphylla periphylla & North Sea: 22, 25 & $\begin{array}{l}\text { Pharmaceuticals, microplastic } \\
\text { filter }\end{array}$ & [76], present study \\
\hline Phyllorhiza punctate * & $\begin{array}{l}\text { Mediterranean Sea, Black Sea: } \\
\qquad 31,32,44\end{array}$ & Food & {$[90]$} \\
\hline Rhizostoma luteum & $\begin{array}{l}\text { Bay of Biscay, Iberia, and } \\
\text { Macaronesia: } 27-29\end{array}$ & Food & {$[31]$} \\
\hline Rhizostoma octopus & $\begin{array}{l}\text { Baltic, North, and Celtic Seas: } \\
\qquad 21-26\end{array}$ & Pharmaceuticals & {$[60]$} \\
\hline Rhizostoma pulmo & $\begin{array}{l}\text { Mediterranean Sea, Black Sea: } \\
\text { 31-36, } 44\end{array}$ & $\begin{array}{l}\text { Food, pharmaceuticals, } \\
\text { animal feed, microplastic filter }\end{array}$ & $\begin{array}{l}{[24,50,51,74]} \\
\text { Present study }\end{array}$ \\
\hline Rhopilema nomadica * & Mediterranean Sea: 31-34 & $\begin{array}{c}\text { Food, pharmaceuticals, } \\
\text { fertilizer, bioactive molecules, } \\
\text { microplastic filter }\end{array}$ & {$[13,65,91,92]$, present study } \\
\hline
\end{tabular}


The distribution, availability, products, markets, and fishing methods of jellyfish were reviewed in the European regions regarding their uses (Table 1), distribution, and investigated fishing seasons (Table 2). Since 2018, a total of $2850 \mathrm{~kg}$ of nine jellyfish species have been harvested by GoJelly partners from Norway, Italy, Slovenia, Israel, Germany, and Portugal for research purposes. The main species included Periphylla periphylla $(1280 \mathrm{~kg}$, $44 \%$ of the catch), harvested in Trondheimsfjorden (Figure 6A); Rhizostoma pulmo (534 kg, $18 \%$ ), harvested in the Mediterranean Sea; and Aurelia spp. (500 kg, 17\%), harvested in the Baltic and the Mediterranean seas. Jellyfish were harvested using gillnets (Mediterranean), benthic trawl (Norway), pelagic trawl (Baltic), landing nets (Adriatic), dip nets (Mediterranean), and a simple $20 \mathrm{~L}$ bucket (Portugal) (Figure 6B). The nets were mainly made from nylon $(89 \%)$; polyethylene fishing nets were rarely used $(11 \%)$. The mesh size varied from 35 to $50 \mathrm{~mm}$. The gear type reflected sampling depth and the vessel used.

The harvested species were used to test their potential in various economic fields: Cotylorhiza tuberculata and Catostylus tagi harvested in Spain (Mar Menor) and Portugal (Lisbon) were tested as feed ingredients for aquaculture and ornamental fish. Texture, biochemical characterization, and temperature effects were investigated for Rhizostoma pulmo and Pelagia noctulica to explore their potential as food for humans. Mucus was extracted from jellyfish caught in the Adriatic Sea (Rhizostoma pulmo and Cotylorhiza tuberculata), Mediterranean Sea (Rhopilema nomadica), and Red Sea (Aurelia sp.) to develop a microplastics filter for use in wastewater treatment plants [23]. Also, the potential use of jellyfish biomass (Aurelia aurita and Cyanea capillata) as a fertilizer was also assessed [15].

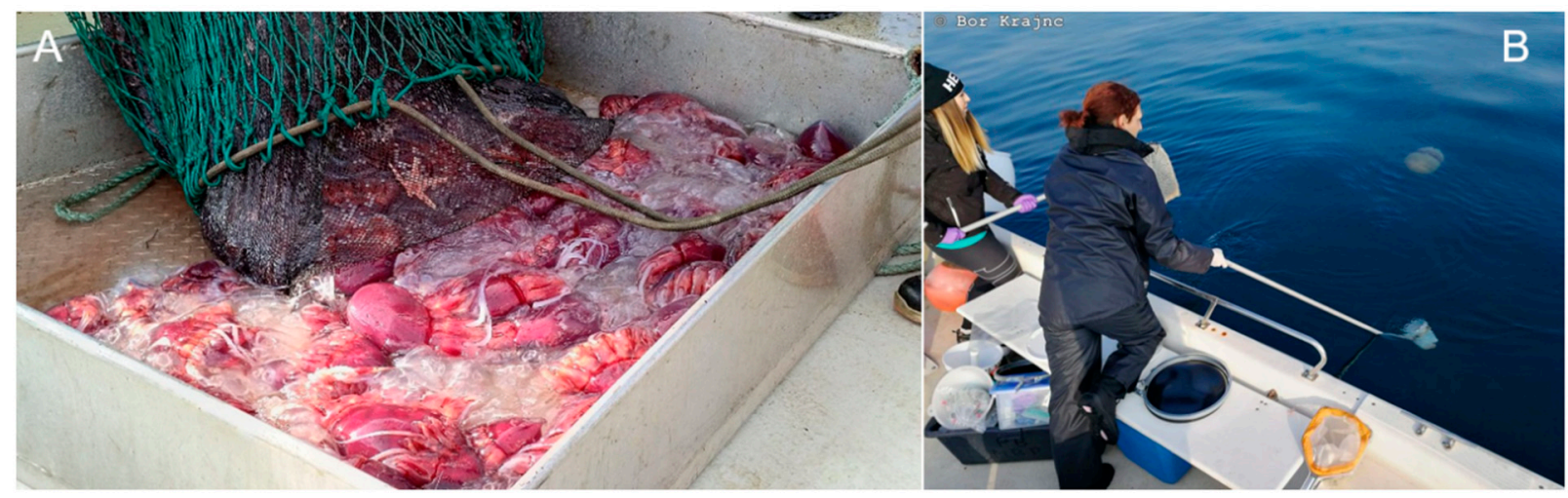

Figure 6. Jellyfish fishing in European seas using (A) benthic trawl for Periphylla periphylla and (B) hand net for Rhizostoma pulmo (Photo credit: A: Nicole Aberle-Malzahn, B: Bor Krajn). 
Table 2. Jellyfish species harvested in the framework of the GoJelly project (2018 to 2020) and their fishing areas and periods. Dark green fields indicate the harvesting period, turquoise fields indicate estimated periods of occurrence.

\begin{tabular}{|c|c|c|c|c|c|c|c|c|c|c|c|c|c|c|}
\hline \multirow{2}{*}{ Area } & \multirow{2}{*}{ Region } & \multirow{2}{*}{ Species } & \multicolumn{12}{|c|}{ Occurrence } \\
\hline & & & January & February & March & April & May & June & July & August & September & October & November & December \\
\hline \multirow{8}{*}{$\begin{array}{l}\text { Mediterranean } \\
\text { Sea }\end{array}$} & \multirow{4}{*}{$\begin{array}{l}\text { Adriatic Sea, Gulf } \\
\text { of Trieste, } \\
\text { Slovenia }\end{array}$} & Rhizostoma pulmo & & & & & & & & & & & & \\
\hline & & $\begin{array}{l}\text { Cotylorhiza } \\
\text { tuberculata }\end{array}$ & & & & & & & & & & & & \\
\hline & & Aurelia solida & & & & & & & & & & & & \\
\hline & & Mnemiopsis leidyi & & & & & & & & & & & & \\
\hline & \multirow{2}{*}{ Ionian Sea, Italy } & Rhizostoma pulmo & & & & & & & & & & & & \\
\hline & & Pelagia noctiluca & & & & & & & & & & & & \\
\hline & Israeli coast & $\begin{array}{l}\text { Rhopilema } \\
\text { nomadica }\end{array}$ & & & & & & & & & & & & \\
\hline & Mar Menor, Spain & $\begin{array}{l}\text { Cotylorhiza } \\
\text { tuberculata }\end{array}$ & & & & & & & & & & & & \\
\hline $\begin{array}{l}\text { Eastern North } \\
\text { Atlantic }\end{array}$ & Tagus, Portugal & Catostylus tagi & & & & & & & & & & & & \\
\hline \multirow{3}{*}{ Baltic Sea } & & Aurelia aurita & & & & & & & & & & & & \\
\hline & & Cyanea spp. & & & & & & & & & & & & \\
\hline & & Mnemiopsis leidyi & & & & & & & & & & & & \\
\hline \multirow[b]{2}{*}{ Norwegian Sea } & & Aurelia aurita & & & & & & & & & & & & \\
\hline & $\begin{array}{l}\text { Trondheimsfjorden, } \\
\text { Norway }\end{array}$ & $\begin{array}{l}\text { Cyanea spp. } \\
\text { Periphylla } \\
\text { periphylla }\end{array}$ & & & & & & & & & & & & \\
\hline
\end{tabular}




\section{Discussion: Towards Establishment of an EU Jellyfish Fishery}

The general attitudes of European (Italian) consumers towards jellyfish as food have recently been examined [14]. Overall, young men with higher education who travel frequently presented more positive attitudes toward this new exotic food, but differences were not always significant and other crowds may thus also be drawn towards eating jellyfish. European jellyfish species could thus be of interest not only for the East-Asian market but should be considered as a new regional food resource, as well as for a variety of new products in western markets. However, many crucial factors need to be considered if jellyfishing should become a common practice in Europe.

\subsection{Environmental Considerations}

Ecosystem stability, minimizing bycatch, and competition with other species are the prime environmental concerns for managers $[10,27,60]$. Further, overexploitation of jellyfish has been shown to create risks to ecosystem stability [11]. A European jellyfishing practice that complies with SDG 14 [93] and sustainably exploits this untapped resource can help protect the marine environment by alleviating existing coastal fishing pressure while providing small-scale fishers with alternative livelihoods.

\subsection{Ecological Interactions and Ecosystem Stability}

Upon founding a jellyfish fishery, competition of the fishery with other species feeding on jellyfish should be considered, as well as impacts on lower trophic levels [10]. Jellyfish are consumed by many marine predators, including fish, birds, turtles, octopuses, sea cucumbers, and crustaceans [94]. Some of the co-occurring species may be endangered, such as large predatory fish and marine mammals [94] or leatherback turtles [95]. Therefore, an extensive fishery seeking to mitigate jellyfish impacts on humans might interfere with natural predator-prey relationships in marine ecosystems and reduce prey availability for consumers. Further, several juvenile fish species aggregate near jellyfish and maintain a commensal relationship with them during crucial developmental phases. A removal of jellyfish would thus have a negative effect on associated biota. In the wider context, large scale jellyfish removal can affect the entire marine food web, from phytoplankton to apex predators, via trophic cascades [27].

Fishery activities for jellyfish need to be performed in a responsible manner to avoid interference with ecosystems' stability. In the case of native jellyfish species, state-of-the-art stock assessments, fishing techniques, and management tools need to be applied to guarantee a sustainable European jellyfish fishery, thus minimizing disturbance to the regional ecological balance upon harvesting. In the case of invasive (harmful) non-indigenous species (NIS), however, different approaches may be considered. For example, a framework for determining whether stocks of NIS should be managed using sustainable or unsustainable exploitation (e.g., overfishing as eradication measures) has recently been developed [52]. Overfishing of jellyfish might pose a concern for ecosystem stability, as it can stimulate the growth of other planktivorous taxa and reduce carbon turnover rates. To avoid overexploitation, the biomass and size composition of jellyfish populations need to be determined and detailed knowledge on demography and reproduction cycles of target jellyfish species need to be addressed. A stock assessment for jellyfish may be achieved similar to how finfish stocks are assessed [96]. New methodologies are being developed for aerial, underwater, and combined estimates of jellyfish biomass and abundances in situ $[44,97,98]$, as well as citizen science approaches [92] and image recognition technology $[98,99]$, that may prove useful for the development of sustainable jellyfish fishery operations.

\subsection{Bycatch}

Commercially or environmentally important species such as fish, sea turtles, and marine mammals may be unintentionally caught by the fishers when associating with jellyfish $[94,95]$. Bycatch depends mostly on the fishing method: while selective hand 
and scoop nets do not entail any significant bycatch, more industrial methods often do. Gillnetting may involve the bycatch of sea turtles or cetaceans, while purse-seining entails a comparably modest amount of bycatch since hauls are short and bycatch may be released with relatively little harm. Bottom and pelagic trawling, however, entail much heavier concerns of bycatch. In Georgia (USA), industrial jellyfish fishing with a pelagic trawl recorded 38 species of fish and three species of invertebrates as bycatch, presumed to be an underestimate of the actual figures. Turtle excluder devices are mandated in Georgia state waters in order to minimize this bycatch [35]. Specific permits for jellyfish fisheries are required by various countries (e.g., Australia, USA, Canada). In Europe, there are still no specific guidelines or regulations concerning jellyfish fisheries. However, the 2013 reform of the Common Fishery Policy (CFP) aims to phase out discarding (and thus bycatch) through a landing obligation, similar to practices in countries like Chile, Iceland, or NewZealand [100]. This EU discard ban presents the EU with an opportunity for landing jellyfish and developing a market for them. For example, 11 pelagic trawl hauls in the Black Sea yielded 9.54 tons of horse mackerel alongside 8.22 tons of Aurelia aurita [78]. Whether jellyfish are counted as part of the landing obligation is unclear, but if a fishery is to be established, the issue of bycatch must be addressed. This includes both jellyfish as bycatch of other fisheries and sensitive species bycaught in targeted jellyfish fisheries.

\subsection{Overexploitation (Overfishing)}

Overexploitation of jellyfish is a concern, as shown for the coastal R. esculentum fishery in the South China Sea [11] and may lead to blooms of less desirable species such as $N$. nomurai [72] or Aurelia spp. [4]. In Liaodong Bay (China), a dramatic increase during the 1980 s in the jellyfishing fleet size, from hundreds of boats to approximately 10,000 vessels, has reduced the jellyfish fishing season from months to single hours over which almost the entire stock is extracted [34]. Jellyfish overexploitation has caused a marked reduction in population size, and subsequent mismanagement has led to an increase in illegal jellyfish fishing, sometimes weeks or even months ahead of the official season opening [34], thus lowering the fishery efficiency considerably. Management should also seek to capitalize on conservation opportunities that arise from fishery establishment by defining no-take zones and seasonal no-take periods where no harvesting activities are allowed. You et al. [34] proposed a quota system for the Chinese jellyfish fishery, and seasonal benthic trawl moratoria have been enforced in the Bohai Sea since the 1980s, protecting R. esculentum polyp beds as part of the benthic habitat [71].

\subsection{Social Considerations}

While East-Asian fisheries are well established, we know relatively little about their social sustainability. Fahrenbruch [28] describes a new Nicaraguan Caribbean fishery for cannonball jellyfish (Stomolophus meleagris) that supplies jellyfish to the Chinese market. The supply chain is driven by what he calls "roving bandits" - foreign-based traders who "typically hold little vested interest in the localities they exploit and seek only to extract as much as they can before moving on to the next location". These traders perform seasonal fisheries that land as much as 5000 tons per day, but leave only high expectations, low revenues, and crumbling processing plants for the locals when blooms are depleted [28]. A further description of the complex and inequitable power dynamics developing among stakeholders with varying needs and interests in the jellyfish fishery was given for the Gulf of California cannonball fishery in Mexico [29]. Similar to Nicaragua and Ecuador, the marginalized and weakened Mexican populations, especially women workers, are the most vulnerable sides when policy guidelines and stern management are not applied [28]. Despite being the most economically important emerging fishery in the Gulf, the cannonball fishery is already described as unsustainable and inequitable [29]. Jellyfish are a high-volume product with narrow profit margins, and their fisheries exhibit large interannual fluctuations. Socioeconomic considerations such as fair employment and wages, safe working conditions for fishers and factory workers, sufficient profit margins, low pollution reusable infrastructure, 
proper product storage and shipping, and clear regulation and long-term planning based on sound fisheries management should therefore be met by decision-makers as early as possible before the establishment of new jellyfish fisheries.

\subsection{Future Perspectives for Jellyfish Fisheries}

Ecosystem-based fishery management (EBFM) under the ecosystem approach (EcAp) is hailed as the comprehensive approach towards sustainable fisheries. It mandates an integrated approach that includes state-of-the-art fishery management within known ecological boundaries, the integration of fishing with other human activities, and the preservation of biodiversity and ecosystem stability alongside the processes necessary to safeguard ecosystem stability and services [101]. A structured framework that considers the range of costs and benefits to ecosystems, ecosystem services, and fisheries should be adopted and regulated regionally but applied locally, thus requiring that fishing nations proactively participate in the regional regulatory process. Management scenarios and options should be developed for a highly seasonal and relatively unstable resource like jellyfish which are species-specific and ecosystem-specific [101]. Alongside ecological considerations, the EBFM of jellyfishing should be fitted with human dimension principles such as employment, well-being, science-based decision-making, and workers' health and safety $[28,102]$. This is pivotal in overcoming socioeconomic challenges and preventing the negative outcomes that may arise from an opportunistic profit-based fishery as reported from Latin America [28,29]. EBFM is typically directed towards managing stocks in a sustainable manner, not eradicating them. For invasive harmful jellyfish species, however, some control can be considered under EBFM [52]. There are at least 40 jellyfish species exploited for food so far and a vast potential exists for other uses of jellyfish products and species. To facilitate both stock assessment and fishery management, countries must strive to improve taxonomic resolution, as only four taxa representing about 15 main species currently appear in FAO records. Additionally, international frameworks like ICES as well as regional bodies like GFCM should play a leading role in formulating basic research and regulations required for stock assessment and fishery management.

Jellyfishing and processing operations are often interlinked, as fresh jellyfish biomass must be rapidly processed to avoid spoilage. While Asian processing typically involves soaking in salts and alum, jellyfish appeal to Western and European taste and standards (e.g., jellyfish chips) may be increased by the reduction of alum usage [24]. This can be achieved by thermal processing as a first stabilizing treatment for jellyfish biomass [24], or by preservation in $96 \%$ ethanol as polyelectrolyte [25]. General attitudes of consumers towards jellyfish as food were recently observed [14] and further testing was advised to pinpoint target markets and seek consumers with a high propensity to accept jellyfish as food.

What Is Required for a Sustainable EU Jellyfishery to Emerge and What Should It Look Like?

A new, sustainable jellyfishery must primarily rely on a solid knowledge base on the demography, reproduction biology, and ecology of the fished jellyfish species and the ecosystem they inhabit (Figure 7). 


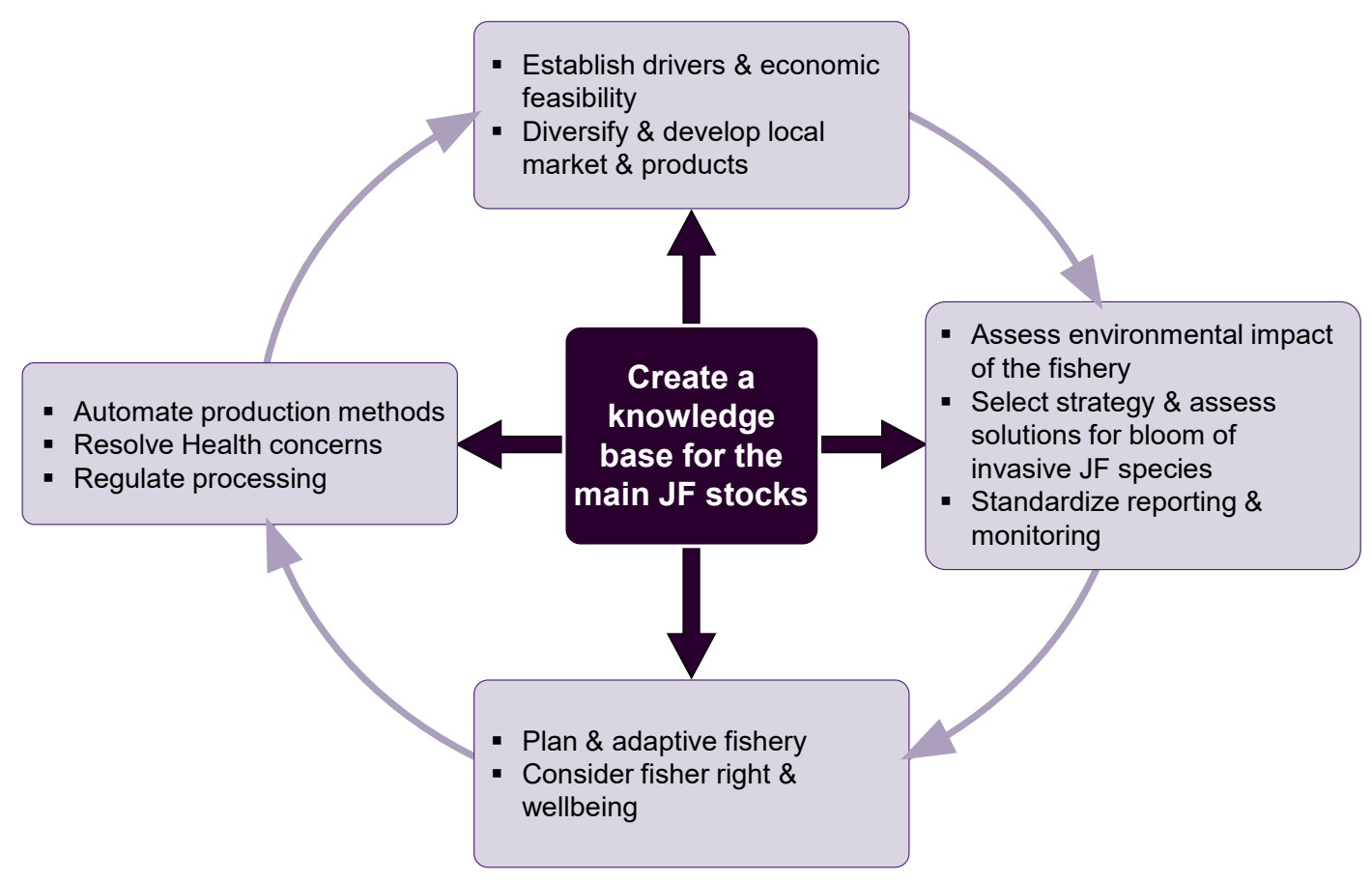

Figure 7. A framework for establishment of a new, sustainable jellyfish fishery.

The motives and risks for fishery establishment should be identified and expectations managed accordingly. Jellyfish stocks should be assessed and monitored to allow for long-term planning alongside adaptive measures. Standardized bycatch surveys must be executed for each fishing method and region, and the fishery should strive to reduce bycatch to minimal levels. Reported data need to be standardized regarding the use of gear and fishing effort, and all catches must be reported with wet weight as the unit.

A rapid enhancement of the entire value chain in exploitation operations can be allowed (inbound logistics, operations, outbound logistics, marketing, sales, service, transportation, communication, and dissemination), but flexibility for downscaling that accommodates the seasonality and instability must be planned. For example, land use issues can be resolved by sharing coastal workspaces with other industries or by planning for adaptive, mobile facilities that are easy to assemble and stow. Processing byproducts (brine) ought to be dealt with in an environmentally responsible way, and odors may require sensitive location of facilities away from population and residential centers. An EU fishery is also likely to modernize traditional labor-intensive extraction methods, depending on region, ecosystem, species, market, and use. Production models that allow for the high spatio-temporal variance of jellyfish fisheries to compromise fisher rights and incomes should be phased out.

We must promote public awareness of the benefits of safe jellyfish consumption as food in the EU, and mandate proper labelling of jellyfish products [88]. To this end, technologies that reduce or eliminate health risks are highly advised [24] and studies that highlight the health benefits of consuming them should be encouraged [50,51].

\section{Conclusions}

Jellyfishing, particularly in Europe, will probably not occur as a bottom-up initiative by fishers. It will be driven by demand, and thus diversification of uses and end products can contribute substantially to fishery development. Creation of a sound knowledge base is key to sustaining any fishery and here we shed light on the needs of such an EU jellyfishery. Issues of monitoring, bycatch, habitat integrity, seasonality, and product life cycle must be considered and managed to assure environmental sustainability, while health, safety, human rights, financial resources, and modularity-adaptivity need to be planned for and 
managed to make sure socio-economic concerns are met. In conclusion, improving our understanding of both human and ecological systems is essential in order to promote the sustainable exploitation of jellyfish.

Author Contributions: Conceptualization, D.E., D.L.A. and J.J.; writing-original draft preparation, D.E.; writing—review and editing, D.E., D.L.A., C.A., J.C.-C., S.K.M.G., N.A., J.J.; visualization, S.K.M.G.; supervision, project administration, funding acquisition, J.J. All authors have read and agreed to the published version of the manuscript.

Funding: This research was funded by the GoJelly Project, EU Horizon 2020, grant number [774499].

Data Availability Statement: Data from the Fishery Statistical Collections and Global Capture Production of FAO was retained from: http:/ / www.fao.org/fishery/statistics/global-capture-production/ en (accessed on 17 August 2021).

Acknowledgments: The authors wish to thank the GoJelly team, and all practitioners and fishers who participated and contributed to the project jellyfishing endeavors.

Conflicts of Interest: The authors declare no conflict of interest.

\section{References}

1. Purcell, J.E.; Uye, S.I.; Lo, W.T. Anthropogenic causes of jellyfish blooms and their direct consequences for humans: A review. Mar. Ecol. Prog. Ser. 2007, 350, 153-174. [CrossRef]

2. Doyle, T.K.; Hays, G.C.; Harrod, C.; Houghton, J.D.R. Ecological and societal benefits of jellyfish. In Jellyfish Blooms; Lucas, C.H., Pitt, K.A., Eds.; Springer: Dordrecht, The Netherlands, 2014; pp. 105-127.

3. Richardson, A.J.; Bakun, A.; Hays, G.C.; Gibbons, M.J. The jellyfish joyride: Causes, consequences and management responses to a more gelatinous future. Trends Ecol. Evol. 2009, 24, 312-322. [CrossRef]

4. Graham, W.M.; Gelcich, S.; Robinson, K.L.; Duarte, C.M.; Brotz, L.; Purcell, J.E.; Madin, L.P.; Mianzan, H.; Sutherland, K.R.; Uye, S.; et al. Linking human well-being and jellyfish: Ecosystem services, impacts, and societal responses. Front. Ecol. Environ. 2014, 12,515-523. [CrossRef]

5. Bosch-Belmar, M.; Milisenda, G.; Basso, L.; Doyle, T.K.; Leone, A.; Piraino, S. Jellyfish Impacts on Marine Aquaculture and Fisheries. Rev. Fish. Sci. Aquac. 2021, 29, 242-259. [CrossRef]

6. Griffin, D.C.; Harrod, C.; Houghton, J.D.R.; Capellini, I. Unravelling the macro-evolutionary ecology of fish-jellyfish associations: Life in the "gingerbread house". Proc. Biol. Sci. 2019, 286, 20182325. [CrossRef] [PubMed]

7. Zimmer, M. GFP: From jellyfish to the Nobel prize and beyond. Chem. Soc. Rev. 2009, 38, 2823-2832. [CrossRef]

8. Leone, A.; Lecci, R.M.; Durante, M.; Meli, F.; Piraino, S. The Bright Side of Gelatinous Blooms: Nutraceutical Value and Antioxidant Properties of Three Mediterranean Jellyfish (Scyphozoa). Mar. Drugs 2015, 13, 4654-4681. [CrossRef] [PubMed]

9. Lee, H.; Pyo, M.J.; Bae, S.K.; Heo, Y.; Choudhary, I.; Hwang, D.; Yang, H.; Kim, J.H.; Chae, J.; Han, C.H.; et al. Nemopilema nomurai jellyfish venom exerts an anti-metastatic effect by inhibiting Smad- and NF-kB-mediated epithelial-mesenchymal transition in HepG2 cells. Sci. Rep. 2018, 8, 2808. [CrossRef] [PubMed]

10. Brotz, L. Jellyfish Fisheries of the World. Ph.D. Thesis, University of British Columbia, Vancouver, BC, Canada, December 2016; 180p.

11. Omori, M.; Nakano, E. Jellyfish fisheries in southeast Asia. Hydrobiologia 2001, 451, 19-26. [CrossRef]

12. Kitamura, M.; Omori, M. Synopsis of edible jellyfishes collected from Southeast Asia, with notes on jellyfish fisheries. Plankton Benthos Res. 2010, 5, 106-118. [CrossRef]

13. Kingsford, M.J.; Pitt, K.A.; Gillanders, B.M. Management of jellyfish fisheries, with special reference to the Order Rhizostomeae. Oceanogr. Mar. Biol. 2000, 38, 85-156.

14. Torri, L.; Tuccillo, F.; Bonelli, S.; Piraino, S.; Leone, A. The attitudes of Italian consumers towards jellyfish as novel food. Food Qual. Prefer. 2020, 79, 103782. [CrossRef]

15. Emadodin, I.; Reinsch, T.; Rotter, A.; Orlando-Bonaca, M.; Taube, F.; Javidpour, J.A. perspective on the potential of using marine organic fertilizers for the sustainable management of coastal ecosystem services. Environ. Sustain. 2020, 3, 105-115. [CrossRef]

16. Ames, C.L. Medusa: A review of an ancient cnidarian body form. Results Probl. Cell Differ. 2018, 65, 105-136.

17. Woo Chun, K.; Damdinsuren, E.; Yeom, K.; Ezaki, T. Effect of Jellyfish Fertilizer Application on Seedling Growth. J. Jpn. Soc. Reveg. Technol. 2011, 37, 155-158. [CrossRef]

18. Borchert, F.; Emadodin, I.; Klu, C.; Rotter, A.; Reinsch, T. Grass growth and N2O emissions from soil after application of jellyfish in coastal areas. Front. Mar. Sci. 2021, 8, 711601. [CrossRef]

19. Barbier, M.; Milo, H. New partnerships for blue biotechnology development-innovative solutions from the sea. In Report on CIESM International Workshop, Monaco, 11-12 November 2010; The Mediterranean Science Commission: Madrid, Spain, 2010; pp. 21-26.

20. Cho, S.; Ahn, J.R.; Koo, J.S.; Kim, S.B. Physicochemical properties of gelatin from jellyfish Rhopilema hispidum. Fish. Aquatic Sci. 2014, 17, 299-304. [CrossRef] 
21. Hsieh, Y.H.P. Use of Jellyfish Collagen (Type II) in the Treatment of Rheumatoid Arthritis. U.S. Patent No. 06894029,17 May 2005. Auburn University.

22. De Domenico, S.; De Rinaldis, G.; Paulmery, M.; Piraino, S.; Leone, A. Barrel Jellyfish (Rhizostoma pulmo) as Source of Antioxidant Peptides. Mar. Drugs 2019, 17, 134. [CrossRef] [PubMed]

23. Freeman, S.; Booth, A.M.; Sabbah, I.; Tiller, R.; Dierking, J.; Klun, K.; Rotter, A.; Ben David, E.; Javidpour, J.; Angel, D.L. Between source and sea: The role of wastewater treatment in reducing marine microplastics. J. Environ. Manag. 2020, $258,110642$. [CrossRef]

24. Leone, A.; Lecci, R.M.; Milisenda, G.; Piraino, S. Mediterranean jellyfish as novel food: Effects of thermal processing on antioxidant, phenolic, and protein contents. Eur. Food Res. Technol. 2019, 245, 1611-1627. [CrossRef]

25. Pedersen, M.T.; Brewer, J.R.; Duelund, L.; Hansen, P.L. On the gastrophysics of jellyfish preparation. Int. J. Gastron. Food Sci. 2017, 9, 34-38. [CrossRef]

26. Pauly, D.; Graham, W.; Libralato, S.; Morissette, L.; Palomares, M.L.D. Jellyfish in ecosystems, online databases, and ecosystem models. Hydrobiologia 2009, 616, 67-85. [CrossRef]

27. Gibbons, M.J.; Boero, F.; Brotz, L. Food for Thought-We should not assume that fishing jellyfish will solve our jellyfish problem. ICES J. Mar. Sci. 2016, 73, 1012-1018. [CrossRef]

28. Fahrenbruch, M.L. 'Like scooping money out of the sea': Chinese luxury seafood consumption, roving bandits, and the boomand-bust jellyfish fishery on the Miskitu Coast of Nicaragua. J. Lat. Am. Geogr. 2018, 7, 209-238. [CrossRef]

29. Cruz-Colín, M.E.; Cisneros-Mata, M.A.; Montaño-Moctezuma, G.; Espejel, I.; Cisneros-Montemayor, A.M.; Malpica-Cruz, L. Analysis of the Gulf of California cannonball jellyfish fishery as a complex system. Ocean Coast. Manag. 2021, 207, 105610.

30. Dong, J.; Wang, B.; Duan, Y.; Wang, A.; Li, Y.; Sun, M.; Chai, Y.; Liu, X.; Yu, X.; Guo, D.; et al. The Natural Ecology and Stock Enhancement of the Edible Jellyfish (Rhopilema esculentum Kishinouye, 1891) in the Liaodong Bay, Bohai Sea, China. In Marine Ecology-Biotic and Abiotic Interactions; Türkoğlu, M., Önal, U., Ismen, A., Eds.; Intech Open: London, UK, 2018; Volume 9, pp. 753-823. [CrossRef]

31. Brotz, L.; Pauly, D. Studying Jellyfish Fisheries: Towards accurate national catch reports and appropriate methods for stock assessments. In Jellyfish: Ecology, Distribution Patterns and Human Interactions; Mariottini, G.L., Ed.; Nova Publishers Hauppauge: New York, NY, USA, 2017; Volume 15, pp. 313-329.

32. Brotz, L.; Schiariti, A.; López-Martínez, J.; Álvarez-Tello, J.; Hsieh, Y.H.P.; Jones, R.P.; Quiñones, J.; Dong, Z.; Morandini, A.C.; Preciado, M.; et al. Jellyfish fisheries in the Americas: Origin, state of the art, and perspectives on new fishing grounds. Rev. Fish. Biol. Fish. 2017, 27, 1-29. [CrossRef]

33. Gul, S.; Jahangir, S.; Schiariti, A. Jellyfish fishery in Pakistan. Plankton Benthos Res. 2015, 10, 220-224. [CrossRef]

34. You, K.; Bian, Y.; Ma, C.; Chi, X.; Liu, Z.; Zhang, Y. Study on the carry capacity of edible jellyfish fishery in Liaodong Bay. J. Ocean Univ. China 2016, 15, 471-479. [CrossRef]

35. Page, J.W. Characterization of bycatch in the cannonball jellyfish fishery in the coastal waters off Georgia. Mar. Coast. Fish. 2015, 7, 190-199. [CrossRef]

36. Bazi, C.C.; Pessatti, M.; Resgalla, C. Utilization of the jellyfish occurring in the bycatch for human consumption in the south of Brazil. Pan-Am. J. Aquat. Sci. 2019, 14, 13-23.

37. Rodrigues, T.; Domínguez-Pérez, D.; Almeida, D.; Matos, A.; Antunes, A. Medusozoans reported in Portugal and its ecological and economical relevance. Reg. Stud. Mar. Sci. 2020, 35, 101230. [CrossRef]

38. Dong, J.; Jiang, L.; Tan, K.; Liu, H.; Purcell, J.E.; Li, P.; Ye, C. Stock enhancement of the edible jellyfish (Rhopilema esculentum Kishinouye) in Liaodong Bay, China: A review. Hydrobiologia 2009, 616, 113-118. [CrossRef]

39. Behera, P.R.; Jishnudev, M.A.; Rao, P.B.; Ghosh, S. An emerging fishery for the jellyfish Crambionella annandalei along the coast of Andhra Pradesh. Mar. Fish. Infor. Serv. Tech. Ext. Ser. 2020, 236, 24-25.

40. Baliarsingh, S.K.; Lotliker, A.A.; Srichandan, S.; Samanta, A.; Kumar, N.; Nair, T.M.B. A review of jellyfish aggregations, focusing on India's coastal waters. Ecol. Process. 2020, 9, 58. [CrossRef]

41. Nishikawa, J.; Srinui, K.; Ohtsuka, S.; Kondo, Y.; Miyake, H.; Lindsay, D.; Iida, A. Jellyfish fisheries in Thailand. Aquabiology 2019, 41, 13-18, (In Japanese with English abstract).

42. Gul, S. Occurrence of Jellyfish Crambionella orsini (Vanhöffen, 1888) (Cnidaria: Scyphozoa) along the coast of Pakistan. World J. Biol. Biotechnol. 2020, 5, 31-32. [CrossRef]

43. López-Martínez, J.; Arzola-Sotelo, E.A.; Nevárez-Martínez, M.O.; Álvarez-Tello, F.J.; Morales-Bojórquez, E. Modeling growth on the cannonball jellyfish Stomolophus meleagris based on a multi-model inference approach. Hydrobiologia 2020, 847, 1399-1422. [CrossRef]

44. Rault, V.; Gaston, T.F. Rapid biomass and size-frequency estimates of edible jellyfish populations using drones. Fish. Res. 2018, 207, 160-164. [CrossRef]

45. Adongo, P.A. Studies on Abundance of Jellyfish in Beach Seine Landings along the Coast of Greater Accra Region of Ghana. Master's Thesis, University of Ghana, Accra, Ghana, 2019.

46. Cruz, M.A. Jellyfish, a Threat or an Opportunity? The Non-Indigenous Blackfordia virginica as a Potential Food Source for Humans and Aquatic Organisms. Master's Thesis, Universidade Do Algarve, Faro, Portugal, 2019.

47. Raposo, A.; Coimbra, A.; Amaral, L.; Gonçalves, A.; Morais, Z. Eating jellyfish: Safety, chemical and sensory properties. J. Sci. Food Agric. 2018, 98, 3973-3981. [CrossRef] [PubMed] 
48. Bleve, G.; Ramires, F.A.; Gallo, A.; Leone, A. Identification of safety and quality parameters for preparation of jellyfish based novel food products. Foods 2019, 8, 263. [CrossRef] [PubMed]

49. Bonaccorsi, G.; Garamella, G.; Cavallo, G.; Lorini, C. A systematic review of risk assessment associated with jellyfish consumption as a potential novel food. Foods 2020, 9, 935. [CrossRef] [PubMed]

50. Basso, L.; Papadia, P.; Rizzo, L.; Migoni, D.; Fanizzi, F.P.; Piraino, S. Trace metals do not accumulate over time in the edible Mediterranean jellyfish Rhizostoma pulmo (Cnidaria, Scyphozoa) from urban coastal waters. Water 2021, 13, 1410. [CrossRef]

51. Stabili, L.; Rizzo, L.; Basso, L.; Marzano, M.; Fosso, B.; Pesole, G.; Piraino, S. The microbial community associated with Rhizostoma pulmo: Ecological significance and potential consequences for marine organisms and human health. Mar. Drugs 2020, 18, 437. [CrossRef]

52. Kleitou, P.; Crocetta, F.; Giakoumi, S.; Giovos, I.; Hall-Spencer, J.M.; Kalogirou, S.; Kleitou, D.; Moutopoulos, D.K.; Rees, S. Fishery reforms for the management of non-indigenous species. J. Environ. Manag. 2020, 280, 111690. [CrossRef] [PubMed]

53. Pitt, K.A.; Lucas, C.H.; Condon, R.H.; Duarte, C.M.; Stewart-Koster, B. Claims That Anthropogenic Stressors Facilitate Jellyfish Blooms Have Been Amplified Beyond the Available Evidence: A Systematic Review. Front. Mar. Sci. 2018, 5, 451. [CrossRef]

54. Gravili, C. Jelly surge in the Mediterranean Sea: Threat or opportunity? Med. Mar. Sci. 2020, 21, 11-21. [CrossRef]

55. Chi, X.; Dierking, J.; Hoving, H.J.; Lüskow, F.; Denda, A.; Christiansen, B.; Sommer, U.; Hansen, T.; Javidpour, J. Tackling the jelly web: Trophic ecology of gelatinous zooplankton in oceanic food webs of the eastern tropical Atlantic assessed by stable isotope analysis. Limnol. Oceanogr. 2021, 66, 289-305. [CrossRef]

56. Dawson, M.N. Some implications of molecular phylogenetics for understanding biodiversity in jellyfishes, with emphasis on Scyphozoa. Hydrobiologia 2004, 530, 249-260.

57. Yuferova, A.A. The impact of different drying modes of scyphozoan jellyfish Rhopilema esculentum and Aurelia aurita on the protein and carbohydrate components in their composition and the possibility of their use as dried prepared food. J. Food. Process. Eng. 2017, 40, e12326. [CrossRef]

58. Scorrano, S.; Aglieri, G.; Boero, F.; Dawson, M.N.; Piraino, S. Unmasking Aurelia species in the Mediterranean Sea: An integrative morphometric and molecular approach. Zool. J. Linn. Soc. 2017, 180, 243-267. [CrossRef]

59. Kienberger, K.; Prieto, L. The jellyfish Rhizostoma luteum (Quoy \& Gaimard, 1827): Not such a rare species after all. Mar. Biodiv. 2018, 48, 1455-1462. [CrossRef]

60. Elliot, A.; Hobson, V.; Tang, K.W. Balancing fishery and conservation: A case study of the barrel jellyfish Rhizostoma octopus in South Wales. ICES J. Mar. Sci. 2017, 74, 234-241. [CrossRef]

61. Kim, D.W.; Baek, T.S.; Kim, Y.J.; Choi, S.K.; Lee, D.W. Moisturizing Effect of Jellyfish Collagen Extract. Soc. Cosmet. Sci. Korean 2016, 42, 153-162.

62. Zhuang, Y.; Hou, H.; Zhao, X.; Zhang, Z.; Li, B. Effects of Collagen and Collagen Hydrolysate from Jellyfish (Rhopilema esculentum) on Mice Skin Photoaging Induced by UV Irradiation. J. Food Sci. 2009, 74, 183-188. [CrossRef] [PubMed]

63. Chancharern, P.; Laohakunjit, N.; Kerdchoechuen, O.; Thumthanaruk, B. Extraction of type A and tybe B gelatin from jellyfish (Lobonema smithii). Int. Food Res. J. 2016, 23, 419-424.

64. Hossain, S.T.; Sugimoto, H.; Asagi, N.; Araki, T.; Ueno, H.; Morokuma, M.; Kato, H. The use of desalinated-dried jellyfish and rice bran for controlling weeds and rice yield. J. Org. Sys. 2013, 8, 28-37.

65. Hussein, O.S.; Saleh, O.I. Effect of soaking in jellyfish on some parameters of wheat and lentil seedlings. J. Environ. Sci. Toxicol. Food Technol. 2014, 8, 32-39. [CrossRef]

66. Miyajima, Y.; Masuda, R.; Kurihara, A.; Kamata, R.; Yamashita, Y.; Takeuchi, T. Juveniles of threadsail filefish, Stephanolepis cirrhifer, can survive and grow by feeding on moon jellyfish Aurelia aurita. Fish. Sci. 2011, 77, 41-48. [CrossRef]

67. Wakabayashi, K.; Sato, H.; Yoshie-Stark, Y.; Ogushi, M.; Tanaka, Y. Differences in the biochemical compositions of two dietary jellyfish species and their effects on the growth and survival of Ibacus novemdentatus phyllosomas. Aquac. Nutr. 2016, 22, 25-33. [CrossRef]

68. Ha, J.; Kim, E.; Lee, B.G.; Yeo, M.K. Capture and toxicity assessment of Ag citrate nanoparticles using jellyfish extract. Mol. Cell. Toxicol. 2020, 16, 431-439. [CrossRef]

69. Lengar, Ž.; Klun, K.; Dogsa, I.; Rotter, A.; Stopar, D. Sequestration of Polystyrene Microplastics by Jellyfish Mucus. Front. Mar. Sci. 2021, 8, 690749. [CrossRef]

70. Chi, X. Preliminary Study on the Principles and Techniques of High-Efficiency Automated Fishing in Jellyfish Fisheries. Master's Thesis, The Ocean University of China, Qingdao, China, 2014.

71. Ye, C.C. The resource and management strategy of jellyfish (Rhopilema esculentum) population in the Liaodong Bay. Fish. Sci. 2006, 25, 591-592. (In Chinese)

72. Kawahara, M.; Uye, S.; Burnett, J.; Mianzan, H. Stings of edible jellyfish (Rhopilema hispidum, Rhopilema esculentum and Nemopilema nomurai) in Japanese waters. Toxicon 2006, 48, 713-716. [CrossRef] [PubMed]

73. FAO. Global Capture Production, Fishery Statistical Collections, Fisheries and Aquaculture Department. In Food and Agriculture Organization of the United Nations. FAO: Rome, Italy. Available online: http:/ / www.fao.org/fishery/statistics/global-captureproduction/en (accessed on 17 August 2021).

74. Ozer, N.P.; Celikkale, M.S. Utilization possibilities of jellyfish Rhizostoma pulmo, as a food in the Black Sea. J. Food Sci. Technol. 2001, 38, 175-178. 
75. FAO. The state of Mediterranean and Black Sea fisheries. In General Fisheries Commission for the Mediterranean; FAO: Rome, Italy, 2018; 172p.

76. Wang, K. The use of untraditional sea food: The commercialization of Norwegian jellyfish, red sea cucumber and whelk. In SINTEF Report; SINTEF: Trondheim, Norway, 2007; 108p.

77. Doyle, T.; Houghton, J.; Buckley, S.; Hays, G.; Davenport, J. The broad-scale distribution of five jellyfish species across a temperate coastal environment. Hydrobiologia 2007, 579, 29-39. [CrossRef]

78. Özdemir, S.; Erdem, E.; Birinci-Özdemir, Z. A preliminary study of bycatch of pelagic trawl fishery in the southern Black sea coast of Turkey: Moon jellyfish Aurelia aurita. Indian J. Geo-Mar. Sci. 2014, 43, 1832-1836.

79. Amaral, L.; Raposo, A.; Morais, Z.; Coimbra, A. Jellyfish ingestion was safe for patients with crustaceans, cephalopods, and fish allergy. Asia Pac. Allergy 2018, 8, e3. [CrossRef] [PubMed]

80. Gueroun, S.K.M.; Torres, T.M.; Dos Santos, A.; Vasco-Rodrigues, N.; Canning-Clode, J.; Andrade, C. Catostylus tagi (Class: Scyphozoa, Order: Discomedusae, Suborder: Rhizostomida, Family: Catostylidae) life cycle and first insight into its ecology. Peer J. 2021, 9, e12056. [CrossRef] [PubMed]

81. Holst, S. Effects of climate warming on strobilation and ephyra production of North Sea scyphozoan jellyfish. Hydrobiologia 2012, 690, 127-140. [CrossRef]

82. D'Ambra, I.; Malej, A. Scyphomedusae of the Mediterranean: State of the Art and Future Perspectives. Cent. Nerv. Syst. Agents Med. Chem. 2015, 15, 81-94. [CrossRef] [PubMed]

83. Fleming, N.E.C.; Harrod, C.; Houghton, J.D.R. Identifying potentially harmful jellyfish blooms using shoreline surveys. Aquacult. Environ. Interact. 2013, 4, 263-272. [CrossRef]

84. Ruiz, J.; Prieto, L.; Astorga, D. A model for temperature control of jellyfish (Cotylorhiza tuberculata) outbreaks: A causal analysis in a Mediterranean coastal lagoon. Ecol. Modell. 2012, 233, 59-69. [CrossRef]

85. Shiganova, T.A.; Mirzoyan, Z.A.; Studenikina, E.A.; Volovik, S.P.; Siokou-Frangou, I.; Zervoudaki, S.; Christou, E.D.; Skirta, A.Y.; Dumont, H. Population development of the invader ctenophore Mnemiopsis leidyi in the Black Sea and other seas of the Mediterranean basin. Mar. Biol. 2001, 139, 431-445.

86. Fuentes, V.L.; Angel, D.L.; Bayha, K.M.; Atienza, D.; Edelist, D.; Bordehore, C.; Gili, J.M.; Purcell, J.E. Blooms of the invasive ctenophore, Mnemiopsis leidyi, span the Mediterranean Sea in 2009. Hydrobiologia 2010, 645, 23-27. [CrossRef]

87. Delpy, F.; Albouy-Boyer, S.; Pagano, M.; Thibault, D.; Blanchot, J.; Guilhaumon, F.; Molinero, J.C.; Bonnet, D. Identifying the drivers of abundance and size of the invasive ctenophore Mnemiopsis leidyi in Northwestern Mediterranean lagoons. Mar. Environ. Res. 2012, 119, 114-125. [CrossRef] [PubMed]

88. Armani, A.; Tinacci, L.; Giusti, A.; Castigliego, L.; Gianfaldoni, D.; Guidi, A. What is inside the jar? Forensically informative nucleotide sequencing (FINS) of a short mitochondrial COI gene fragment reveals a high percentage of mislabeling in jellyfish food products. Food Res. Int. 2013, 54, 1383-1393. [CrossRef]

89. Frazão, B.; Campos, A.; Osório, H.; Thomas, B.; Leandro, S.; Teixeira, A.; Vasconcelos, V.; Antunes, A. Analysis of Pelagia noctiluca proteome Reveals a Red Fluorescent Protein, a Zinc Metalloproteinase and a Peroxiredoxin. Protein. J. 2017, 36, 77-97. [CrossRef] [PubMed]

90. Gueroun, S.K.M.; Yahia, O.K.D.; Deidun, A.; Fuentes, V.; Piraino, S.; Yahia, M.N.D. First record and potential trophic impact of Phyllorhiza punctata (Cnidaria: Scyphozoa) along the north Tunisian coast (South Western Mediterranean Sea). Ital. J. Zool. 2015, 82, 95-100. [CrossRef]

91. Lotan, A.; Fine, M.; Ben-Hillel, R. Synchronization of the life cycle and dispersal pattern of the tropical invader scyphomedusan Rhopilema nomadica is temperature dependent. Mar. Ecol. Prog. Ser. 1994, 109, 59-65. [CrossRef]

92. Edelist, D.; Guy-Haim, T.; Kuplik, Z.; Zuckerman, N.; Nemoy, P.; Angel, D.L. Phenological shift in swarming patterns of Rhopilema nomadica in the Eastern Mediterranean Sea. J. Plankton Res. 2020, 42, 211-219. [CrossRef]

93. United Nations. Transforming Our World: The 2030 Agenda for Sustainable Development Resolution Adopted by the General Assembly on 25 September 2015, Seventieth Session, Agenda Items 15 and 116. A/RES/70/1. Available online: http:/ /www.un. org/ga/search/view_doc.asp?symbol=A/RES/70/1\&Lang=E (accessed on 2 September 2021).

94. Hays, G.C.; Doyle, T.K.; Houghton, J.D.R. A Paradigm Shift in the Trophic Importance of Jellyfish? Trends Ecol. Evol. 2018, 33, 874-884. [CrossRef] [PubMed]

95. Nordstrom, B.; James, M.C.; Martin, K.; Worm, B. Tracking jellyfish and leatherback sea turtle seasonality through citizen science observers. Mar. Ecol. Prog. Ser. 2019, 620, 15-32. [CrossRef]

96. Brotz, L.; Pauly, D. Jellyfish populations in the Mediterranean Sea. Acta Adriat. 2012, 53, 211-230.

97. Schaub, J.; Hunt, B.; Pakhomov, E.; Holmes, K.; Lu, Y.; Quayle, L. Using unmanned aerial vehicles (UAVs) to measure jellyfish aggregations. Mar. Ecol. Prog. Ser. 2018, 591, 29-36. [CrossRef]

98. Hamel, H.; Lhoumeau, S.; Wahlberg, M.; Javidpour, J. Using Drones to Measure Jellyfish Density in Shallow Estuaries. J. Mar. Sci. Eng. 2021, 9, 659. [CrossRef]

99. Gauci, A.; Deidun, A.; Abela, J. Automating jellyfish species recognition through faster region-based convolution neural networks. Appl. Sci. 2020, 10, 8257. [CrossRef]

100. Guillen, J.; Holmes, S.J.; Carvalho, N.; Casey, J.; Dörner, H.; Gibin, M.; Mannini, A.; Vasilakopoulos, P.; Zanzi, A. A Review of the European Union Landing Obligation Focusing on Its Implications for Fisheries and the Environment. Sustainability 2018, 10, 900. [CrossRef] 
101. Bastardie, F.; Brown, E.J.; Andonegi, E.; Arthur, R.; Beukhof, E.; Depestele, J.; Döring, R.; Eigaard, O.R.; García-Barón, I.; Llope, M.; et al. A Review Characterizing 25 Ecosystem Challenges to Be Addressed by an Ecosystem Approach to Fisheries Management in Europe. Front. Mar. Sci. 2021, 7, 629186. [CrossRef]

102. Hornborg, S.; van Putten, I.; Novaglio, C.; Fulton, E.A.; Blanchard, J.L.; Plagányic, É.; Bulman, C.; Sainsbury, K. Ecosystem-based fisheries management requires broader performance indicators for the human dimension. Mar. Pol. 2019, 108, 103639. [CrossRef] 